\title{
PERMASALAHAN PENDIDIKAN DI INDONESIA
}

\author{
Herlina \\ Email:2010128320002@mhs.ulm.ac.id \\ Program Studi Pendidikan IPS Fakultas Keguruan dan Ilmu Pendidikan \\ Universitas Lambung Mangkurat \\ Banjarmasin
}

\begin{abstract}
Abstrak
Pendidikan adalah hal pokok yang harus dipenuhi oleh suatu individu atau masyarakat, karena dengan pendidikan dapat menentukan arah kehidupan berbangsa maupun bermasyarakat. Pendidikan di indonesia terbagi menjadi 3 bagian yaitu pendidikan formal, informal dan nonformal. Pendidikan tidak lepas dengan adanya suatu permasalahan yang muncul, masalah tersebut seperti masalah efesiensi pengajaran, masalah keprofesionalan dan kesejahteraan guru, tidak meratanya pendidikan, serta sarana dan prasarana yang tidak memadai. Berbagai masalah yang muncul tersebut merupakan permasalahan yang harus mendapat perhatian dari pemerintah maupun warga negaranya, sehingga mendapat suatu upaya untuk memecahkan permasalahan tersebut.
\end{abstract}

\section{PENDAHULUAN}

Pendidikan adalah suatu hal yang penting bagi setiap orang karena dengan pendidikan bisa mengembangkan kemampuan seseorang, pendidikan juga hal pokok yang harus dipenuhi oleh setiap individu, karena pada dasarnya pendidikan tidak akan lepas dari segala aktivitas yang dilakukan manusia. Oleh karena itu, Pendidikan terbagi menjadi tiga yaitu pendidikan formal, pendidikan in-formal, dan pendidikan non-formal. Pendidikan formal ialah pendidikan yang terstruktur yang diselenggarakan disekolah seperti PAUD,SD,SMP,SMA hingga perguruan tinggi. Sedangkan pendidikan informal adalah pendidikan yang terdapat di dalam ruang lingkup keluarga seperti halnya orangtua yang mengajarkan anaknya sopan santun, etika, moral dan sosial. Pendidikan non-formal merupakan jalur di luar pendidikan formal yang dapat dilaksanakan secara terstruktur. Tujuan dari pendidikan adalah untuk mewujudkan manusia yang beriman dan bertakwa kepada Tuhan Yang Maha Esa yang memiliki akhlak mulia serta dapat mengendalikan hawa nafsunya dalam bermasyarakat maupun berbudaya. Pendidikan sebagai suatu sistem terbuka tidak lepas dari adanya suatu masalah, baik itu masalah 
mikro maupun masalah makro. Masalah makro adalah masalah yang timbul dalam pendidikan itu sebagai suatu sistem dengan sistem laiinnya yang lebih luas seperti kurang meratanya pendidikan, rendahnya mutu pendidikan, masalah efesiensi, relevansi dan lain-lain. sedangkan masalah mikro adalah masalah yang timbul dalam pendidikan itu sendiri sebagai suatu sistem seperti masalah kurikulum, andministrasi pendidikan dan sebagainya. Dengan adanya permasalahan yang sering terjadi di indonesia, maka dari itu kita semestinya mengidentifikasikan permasalahan tersebut sehingga dengan mengidentifikasi permasalahan pendidikan kita dapat mengetahui letak permasalahan yang terjadi di indonesia dan berusaha untuk memberikan solusi dari permaslahan tersebut.

\section{METODE PENELITIAN}

Metode penelitian yang digunakan dalam penelitian ini adalah metode kualitatif. Metode kualitatif adalah metode yang bersifat diskriptif yaitu pengumpulan dari berbagai sumber ilmiah seperti artikel maupun jurnal ilmiah yang di dapat kemudian dianalisis sehingga mendapat sebuah kesimpulan dari apa yang diteliti.

\section{PEMBAHASAN}

Pendidikan merupakan suatu unsur yang tidak dapat dipisahkan dari manusia karena setiap individu pasti mengalami pendidikan. Pendidikan dapat menentukan arah, tujuan, maupun makna dari kehidupan ini. Namun pendidikan tidak akan terhindar dari adanya masalah-masalah dalam pendidikan. Permasalahan-permasalahan tersebut seperti masalah efesiensi pengajaran, masalah keprofesionalan dan kesejahteraan guru, tidak meratanya pendidikan, serta sarana dan prasarana yang tidak memadai. Beberapa masalah efesiensi pengajaran disekolah yaitu seperti mahalnya biaya pendidikan disekolah. Oleh karena itu banyak orangtua yang memiliki perekonomin yang rendah tidak mampu menyekolahkan anaknya ke sekolah, walaupun sekolah ada yang membebaskan pembayaran artinya sekolah tidak melakukan pembayaran, namun dalam pendidikan diperlukan suatu perlengkapan sekolah yang harus dipenuhi oleh siswa seperti perlengkapan pada buku dan lain-lain, biaya transportasi yang ditempuh juga 
berperan dalam hal ini apalagi orang yang memilki rumah jauh dari sekolah, maka akan mengeluarkan biaya untuk kesekolah tersebut. Selain mahalnya pendidikan di indonesia, masalah lain yang termasuk dalam permasalahan pendidikan di indonesia yaitu faktor kompetensi profesionalisme guru. Kompetensi profesionalisme guru dalam hal ini adalah kemampuan seorang guru bagaimana cara menyampaikan materi pembeljaran secara luas dan mendalam, Sehingga peserta didik akan mudah memahami materi yang akan di sampaikan tersebut. Pentingnya peranan seorang guru tentunya akan mengarah pada suatu tanggung jawab untuk menjalankan suatu profesi yang menjadi tanggung jawabnya dengan sikap profesionalisme yang tinggi. Dalam menjalankan profesinya guru harus melaksankan fungsinya yaitu secara moral ia harus membimbing anak didik dengan mengajarkan berbagai hal yang positif dan juga mendidik agar menjadi manusia atau warga negara yang berkualitas serta bermanfaat bagi kehidupan bermasyarakat, berbangsa dan bernegara. Berkenaan dengan peran seorang guru, maka keprofesionalan seorang guru sangatlah penting untuk memenuhi suatu tuntunan masyarakat. Berbagai kendala yang dihadapi sekolah termasuk daerah terpencil adalah karena kekurangan guru yang sesuai dengan kebutuhan, kebutuhan yang dimaksud adalah suatu bidang studi yang sesuai dengan pendidikan terakhir guru. Karena kekurangan tenaga pendidikan atau guru tersebut maka terpaksa sekolah mengambil kebijakan yang tidak sesuai dengan pendidikan guru atau bidang keahliannya. Contohnya guru yang memilki bidang ke ahlian di bidang matematika, dapat juga mengajar siswa di bidang bahasa indonesia karena disebabkan kurangnya tenaga pendidik tersebut.

Faktor Perubahan Kurikulum juga menjadi permasalahan pendiidkan di indonesia karena jatuh bangunnya kualitas pendidikan di indonesia disebabkan oleh sering berubahnya kurikulum yang diterapkan dalam proses pembelajaran. Kurikulum pembelajaran merupakan suatu hal yang merupakan pijakan guru dalam menentukan arah pembelajarannya, bagaimana tujuan yang harus dicapai, perubahan tingkah laku apa yang harus dilakukan, apa kesulitan serta bagaimana tindakan yang tepat agar bisa melanjutkan pendidikan selanjutnya. Perubahan kurikulum ini menyebabkan kepala sekolah beserta guru-guru sibuk memperbaiki suatu perangkat pembelajaran dengan 
pembelajaran terkini atau yang baru dirubah tersebut. Selain permasalahan pendidikan yang disebutkan diatas masih banyak lagi permasalahan pendidikan yang ada di indonesia, salah satunya juga pada masalah pemerataan pendidikan, dimana isu ini berkaitan dengan sistem pendidikan dalam menyiapkan peluang yang sangat besar agar dapat mengenyam suatu pendidikan. Permasalahan pemerataan pendidikan dapat terjadi karena kurangnya kordinasi antara pemerintah pusat dengan pemerintah daerah, hal tersebut menyebabkan terputusnya komunikasi antara keduanya, selain itu juga terjadi karena kurang berdayanya lembaga pendidikan untuk melaksanakan proses pendidikan, hal ini bisa terjadi jika pemerintah dalam mengontrol pendidikan yang dilakukan tidak menjangkau daerah-daerah yang terpencil. Oleh sebab itulah yang akan mengakibatkan mayoritas penduduk indonesia yang masuk usia sekolah tidak bisa mengenyam pendidikan sebagaimana yang diharapkan. Ada banyak cara yang dapat dilakukan pemerintah dalam mengatasi masalah pemerataan pendidikan ini yaitu dengan menyediakan fasilitas dan sarana belajar bagi masyarakat yang wajib mendapatkan pedidikan contohnya seperti di daerah-daerah yang terpencil. 


\section{SIMPULAN}

Pendiidkan merupakan hal pokok yang harus dipenuhi oleh setiap individu, karena pada dasarnya pendidikan tidak akan lepas dari segala aktivitas yang dilakukan manusia. Pendidikan terbagi menjadi tiga yaitu pendidikan formal, pendidikan informal, dan pendidikan non-formal. Di indonesia pendidikan tidak akan lepas dari adanya sebuah masalah-masalah yang di hadapi. Permasalahan tersebut seperti masalah efesiensi pengajaran, masalah keprofesionalan dan kesejahteraan guru, tidak meratanya pendidikan, serta sarana dan prasarana yang tidak memadai. Selain permasalahan yang disebutkan tersebut masih banyak lagi masalah-masalah yang dihadapi dalam pendidikan seperti lemahnya sistem pendidikan yang dilakukan dari segi pengajaran yang disebabkan dari keprofesionalan seorang guru, proses belajar dan pembelajaran peserta didik yang kurang efektif, masalah biaya pendidikan, dan lain-lain. Berbagai masalah yang muncul tersebut merupakan permasalahan yang harus mendapat perhatian dari pemerintah maupun warga negaranya. Karena dengan pendidikan akan dapat dilihat maju mundurnya suatu bangsa. Permasalahan ini dapat diselesaikan dengan berkonstribusinya antara orangtua, masyarakat, maapun sekolah atau lembaga lain yang berpengaruh. 


\section{DAFTAR PUSTAKA}

Agustin, I. N. N., \& Supriyanto, A. (2020). PERMASALAHAN PENDIDIKAN DI INDONESIA. In Seminar Nasional Arah Manajemen Sekolah Pada Masa Dan Pasca Pandemi Covid-19.

Arisanty, D., Putro, H. P. N., Wahyu, W., Anis, M., Arifin, Z., \& Syarifuddin, S. (2018). Pengembangan Keprofesionalan Guru Melalui Penelitian Tindakan Kelas (PTK) di SMP Negeri 1 Alalak Kec. Alalak Kab. Barito Kuala.

Indriyani, I. E., Syaharuddin, S., \& Jumriani, J. (2021). Social Interaction Contents on Social Studies Learning to Improve Social Skills. The Innovation of Social Studies Journal, 2(2), 93-102.

Jumriani, J., Mutiani, M., Putra, M. A. H., Syaharuddin, S., \& Abbas, E. W. (2021). The Urgency of Local Wisdom Content in Social Studies Learning: Literature Review. The Innovation of Social Studies Journal, 2(2), 103-109.

Megawanti, P. (2015). Meretas Permasalahan Pendidikan Di Indonesia. Formatif: Jurnal Ilmiah Pendidikan MIPA, 2(3).

Priscilla, D. (2019). Permasalahan Pendidikan di Indonesia.

Putro, H. P. N. (2013). Pengembangan Pembelajaran IPS dalam Kurikulum 2013. Mewacanakan Pendidikan IPS, 39.

Putro, H. P. N. (2020). HISTORICAL THINKING IN LEARNING SOCIAL STUDIES EDUCATION.

Putro, H. P. N., Jumriani, J., Darmawan, D., \& Nuryatin, S. (2020). Social Life of the Community: Perspective of Riverbanks Community in Sungai Jingah, Banjarmasin. The Kalimantan Social Studies Journal, 1(2), 151-158.

Putro, P. U. W. (2020). PERILAKU ORGANISASI.

Wahidah, M. N., Putro, H. P., Syaharuddin, S., Prawitasari, M., Anis, M. Z. A., \& Susanto, H. (2021). DINAMIKA PENDIDIKAN DASAR ISLAM SABILAL MUHTADIN BANJARMASIN (1986-2019). PAKIS (Publikasi Berkala Pendidikan Ilmu Sosial), 1(1). 